Daria Shapovalova, Eduard Gallimullin, and Ekaterina Grushevenko dshapovalova@abdn.ac.uk This paper is a pre-copy edit version of the paper forthcoming in Energy Policy

\title{
Russian Arctic Offshore Petroleum Governance: The Effects of Western Sanctions and Outlook for Northern Development
}

\begin{abstract}
The Arctic has historically been a strategically important region for Russia, from before the Cold War to the recent efforts in increasing shipping along the Northern Sea Route. Russia holds the largest share of petroleum resources in the Arctic, the governance model for which has been changing over the past few decades based on the current political priorities, external events, and geophysical changes in the region. Following the conflict in Ukraine, the European Union and the United States adopted sanctions limiting the cooperation between Russian and western companies for Arctic offshore petroleum development. This paper analyses transformation in national governance of natural resources in the Russian Arctic, focusing on offshore oil and gas. It provides historical background of the governance model to facilitate the analysis of the effects of western sanctions on the current resource development and its regulation. Through the analysis of legal and policy documents, this paper provides an outlook for future developments in the Russian Arctic offshore resource governance.
\end{abstract}

\section{Keywords}

Russia, Arctic, governance, north, sanctions, oil and gas 


\section{Introduction}

Russia accounts for more than half of the Arctic Ocean coastline and as such holds sovereign rights for most Arctic offshore petroleum resources, predominantly gas. The Northern Sea Route (NSR) along the Russian coast is projected to become the primary shipping lane for the Arctic resources. While Russia is an active participant in the Arctic Council and has strong ties with neighbouring Norway, its conflict with Ukraine led to the adoption of economic sanctions by the European Union (EU) and the United States of America (US). These sanctions inter alia prohibit western companies to sell, supply, transfer or export technology and finance to Russian companies for offshore oil developments in the Arctic. They, furthermore, impose restrictions on certain companies and individuals. While Russian Arctic and energy policies set out ambitious plans for Arctic resource development, the limitations on foreign capital and technology affect both the pace and the scale of such development. They also have policy implications, with Russia initiating the development and improvement of domestic technologies, increased State support for Russian oil and gas companies, and enhanced cooperation with partners in the East.

The analysis of Russian energy development has been growing in western literature, but most sanctions-related work is from 2014-2016. Sidortsov examined the legal framework for offshore petroleum development in the Russian Arctic [1], and the climate impacts of such developments [2,3]. A recent collection edited by Tynkkynnen et al. [4] comprehensively examines energy resources of the Russian Arctic from commercial, economic, security, and social perspectives. Researchers based at the Fridtjof Nansen Institute regularly publish indepth analyses of Russian politics, including issues related to oil and gas [5-8]. There has been energy-related scholarship on Russian cooperation with Norway in the Barents Sea, and on the 
NSR $[9,10]$. Russian Arctic energy policy specifically has been examined by Øverland, who notes striking similarities between Russian and western Arctic policy proclamations [11].

The effects of western sanctions have been examined by Russian and western scholars with a general consensus that equipment export ban is not likely to have immediate effects, unlike the financial restrictions. Shortly after the adoption of the sanctions, Konoplyanik et al. published a comprehensive assessment of their effects on resource development in the Russian Arctic [12]. Aalto and Forsberg argue that while sanctions limited resource development geography, they had substantially less effect on the financial or institutional capacity [13]. Already in the first year of the imposition of western sanctions, some commentators predicted that the shortto-medium-term effects of sanctions could be compensated by Russian access to resources, but long-term sanctions could have more severe effects on the Russian economy [14,15]. Fjaertoft and $\varnothing v e r l a n d$ argue that the equipment export ban will have limited effects, compared to 'immediate and significant' effect of the financial sanctions [16].

There is a pressing need to reassess these policies in light of the updated policy documents, and in the context of wider legal and political developments. This paper builds on the existing literature to address the effects of western sanctions on resource development in the Arctic and its governance. It utilises doctrinal analysis of the law and policy documents on Russian Arctic resource governance and the sanctions adopted by the EU and the US. To that end, the paper starts with the consideration of the historical development of the Russian Arctic resources governance regime in section 2. It then turns to the analysis of the sanctions and their impact on the resource development in the Russian Arctic, in section 3. Section 4 examines Russian Arctic resource governance post-sanctions, noting the increasing focus and State support for resource development, and import substitution trends. The paper concludes that, in practical terms, the sanctions resulted in delays of Russian Arctic petroleum development, but have also not deterred the ambition for Arctic development and forced prioritisation of domestic 
development in upstream technologies and increased State support for Arctic petroleum projects.

\section{Historical development of Russian Arctic resource governance}

The focus on resource development in the North can be traced throughout the twentieth century and multiple regime changes in Russia. This section briefly outlines the role of Arctic resources in the Russian Arctic policies, institutions, and economy in the period before the adoption of sanctions.

The Russian North has always existed as a substantial resource base for the rest of the country. The sparsely populated and difficult-to-reach northern regions provided the Russian Empire's treasury with revenues from forest resources, fish, and fur exports. The Soviet State developed new infrastructure and built cities in the North, all to exploit large deposits of metals and minerals. A project of this scale was only possible through processes of colonisation, forced labour, and substantial investment into the development of the North, enabled by nationalising private property [17].

One of the first geological appraisals, organised by the Northern Expedition in 1920, estimated sizable mineral resources in the Russian Arctic and prompted further research into the extent of resources in the region. In 1930, the first Arctic oil field, Chibyuskoe, was discovered in the Republic of Komi [18].

To transport all these new resources through the NSR, the government established a separate agency in 1936. Glavsevmorput (or Chief Directorate of the NSR) was responsible for geological research, prospecting and exploration for natural resources, and organising their further exploitation. In 1948, the Arctic Geology Research Institute was established, playing a 
vital role in the boom of the petroleum activities in the Russian Arctic in the 1960s [19]. Gradually, these developments led to the resource-oriented economic model and resource exploitation paradigm later inherited by the Russian Federation [20].

During the Soviet period, the North was an attractive work destination, both in terms of labour conditions and from a financial perspective [21]. In a closed economic system, it was one of the few places where one could legally earn a substantial amount of money [22]. However, after the transition to the market economy, the migration pattern shifted towards the central and southern regions. The State's involvement has been reduced in all social and economic sectors, with Arctic being a notable exception. This region seems to have absorbed the results of State ownership and central planning policies [23].

As a result, after the collapse of the Soviet Union, the Arctic region has been particularly affected. The level of resource development has drastically declined, with the leading petroleum-producing regions seeing double the losses in 1995 compared to 1990 (see Table 1). The numbers only started improving after Putin came to power in 2000 and the ruling elite began expressing concerns over the long-term outlook for resource development in the country [24].

\begin{tabular}{|l|c|c|c|c|}
\hline Region & $\mathbf{1 9 9 0}$ & $\mathbf{1 9 9 5}$ & $\mathbf{2 0 0 0}$ & $\mathbf{2 0 0 5}$ \\
\hline Tyumen Oblast & 365342 & $201592(-55,2 \%)$ & 213469 & 320237 \\
\hline $\begin{array}{l}\text { Khanty-Mansi } \\
\text { Autonomuc Okrug }\end{array}$ & 305981 & $169179(-55,3 \%)$ & 180888 & 268002 \\
\hline $\begin{array}{l}\text { Yamalo-Nenets } \\
\text { Autonomuc Okrug }\end{array}$ & 59352 & $32371(-54,5 \%)$ & 32025 & 50784 \\
\hline Russian Federation & $\mathbf{5 1 6 1 8 3}$ & $\mathbf{3 0 6 8 2 7}(-\mathbf{5 9 , 4 \% )}$ & $\mathbf{3 2 3 5 1 7}$ & $\mathbf{4 7 0 1 7 5}$ \\
\hline
\end{tabular}

Table 1. Oil production, including natural gas condensate (thousands of tons)

Source: Rosstat, 2007 (Russian Statistics) 
Russian oligarchs, who bought the oil companies at lowered auction prices, did not make longterm plans in the crisis socio-economic conditions. Furthermore, foreign investors were cautious of entering the Russian petroleum industry as foreign investment protection legislation was yet to be developed. To facilitate revenue generation for increasing needs of the newly independent State, the government used Gazprom, former Ministry of Gas Industry. The government often used Gazprom's foreign currency export revenues as a reserve fund for settling debts on welfare costs [25].

The oil industry, on the other hand, was less monopolised and witnessed the boom and bust of multiple companies, and various mergers and acquisitions by larger actors. Competition in the oil sector has often been politicised, as evidenced by the infamous Yukos case [26]. The federal government was determined to strengthen the region, while not devolving too much power to the separate subregions of the Russian Arctic zone, by e.g. establishing a federal committee on socio-economic development of the North in 1993 [27].

In 2007, the Arctic entered the geopolitical spotlight after the Russian ocean floor mapping expedition planted, to great fanfare and media headlines, a titanium flag on the seabed under the North Pole, a measure perceived by some as akin to a 'fifteenth-century land grab' [28]. Shortly thereafter, the US geological survey's estimation that $22 \%$ of the world's undiscovered oil and gas exists in the Arctic has turned the media's eyes on the region [29]. While globally this created concerns over potential conflict over Arctic resources, domestically, the Russian government was actively drafting new policies for regional development. Thus, in 2008 the government adopted the Fundamentals of the Russian Federation State Policy on the Arctic until 2020' [30], signalling the new stage in the Russian Arctic resource governance. ${ }^{1}$

\footnotetext{
${ }^{1}$ The document was updated in April 2020 [94].
} 
The Arctic gradually became a political term in Russia [32], and it was becoming clear that it needed to be developed as a separate, self-sufficient macro-region. In 2013-2014, two important policy documents were adopted: 1) the Strategy; and 2) the State Programme on Social and Economic Development in the Arctic Zone until 2020 [33,34]. The Strategy elaborated on the mechanisms necessary to achieve the goals set for Arctic development. It emphasised geological prospecting of the Arctic continental shelf, modernising the infrastructure, and developing the NSR. It also recognised the limitations of Russian technology for developing offshore Arctic resources as well as the depreciation of transport, industrial, and energy infrastructure in the region. To implement the Strategy, the State Programme on Arctic economic development was adopted the following year focusing on onshore developments and including funding allocations for port and liquefied natural gas (LNG) facilities along the Arctic coast.

In the spirit of strengthening State control over the northern resources, petroleum legislation was amended to only allow State companies (ownership over 50\%) with at least five years of experience of drilling on the Russian continental shelf to apply for Arctic offshore oil and gas licenses [31]. Furthermore, in 2017, the Merchant Shipping Code was amended to establish exclusive rights for Russian flag-carrying vessels to transport petroleum products along the NSR [95].

In 2014, in response to the Russian involvement in the Eastern-Ukrainian conflict, the EU and US adopted economic sanctions prohibiting western companies to sell, supply, transfer or export technology to Russian companies for the purposes of oil development in the Arctic [3538]. Against that background, the current power structure of the Russian petroleum industry was formed. It included two State-owned 'giants' - Gazprom and Rosneft', with its multiple subsidiaries; private Novatek and Lukoil; and large regional players, such as Tatneft' and Surgutneftegaz. 


\section{Western sanctions and Arctic resource development}

Both the EU and US sanctions target, among other things, the offshore petroleum industry in Russia. To analyse the role of sanctions in Arctic petroleum development, this section considers the role of foreign companies in the Russian Arctic pre-sanctions, and the contents and effects of the sanctions on the existing projects.

\subsection{Foreign companies in Russian Arctic petroleum sector pre-Sanctions}

In the post-Soviet period, foreign oil companies played the key role in restoring the petroleum production rates in Russia [39]. Today, the involvement of foreign companies in the Russian Arctic shelf projects is limited. As noted above, only State companies with at least five years of experience of drilling on Russian continental shelf can apply for offshore licenses [31], which in practice means only Rosneft', Gazprom, and their subsidiaries.

The five-year experience requirement further precludes new companies incorporated by foreign companies in partnership with Gazprom and Rosneft' to apply for licenses. The law does not explain whether the mother-companies' experience would count. Russian experts conclude that it would not [40], which rules out foreign companies entering as minority shareholders in specially created companies (special purpose vehicles or SPVs) - a model widely utilised pre-2009 and for onshore developments. Nevertheless, despite strong State control, foreign companies have been essential to exploration and production activities in the region, not as license holders, but as partners and contractors with technology, equipment, and access to capital. 


\subsection{Sanctions: technology export ban}

Sanctions prohibit the sale, supply, transfer, export, and financing of equipment for oil production in deep water, shale formations, and above the Arctic Circle [37,38]. As discussed above, by the time sanctions were adopted, foreign companies have already been prohibited from holding licenses in the Russian Arctic waters. However, their participation through service contracts with Rosneft' and Gazprom was essential for active development of Arctic petroleum resources offshore. Without access to foreign equipment, expertise, and finance, it falls on Rosneft' and Gazprom to conduct all exploration and production work, which they might not be prepared to do in the short-term. Despite strong State control of Russian Arctic offshore resources, both government and industry agree that State companies need the expertise and technology of foreign partners $[41,42]$.

Overall, experts estimate that when sanctions were imposed the development of Russian Arctic offshore resources had between 80 and 90\% dependency on import technologies [12]. In 2015, Gazprom, Novatek, and Rosneft' requested the postponement of their existing licenses, citing sanctions, low oil prices, and difficulty in accessing finance. At the time, Rosneft' requested the biggest number of such postponements [43]. While Gazprom was developing expertise in Arctic offshore projects through Prirazlomnaya, Rosneft's Arctic projects relied heavily on western partners and its operations were arguably affected more. Thus, for example, when ExxonMobil suspended its cooperation with Rosneft' at the Pobeda field despite a significant discovery, further development at the field was postponed [44].

Delays in production are costly and problematic in the oil and gas industry, but it appears that the first steps are being made in attempts to revitalise the Rosneft's Arctic ambitions. In July 2019, it was announced that Rosneft' is going ahead alone at the nearby license block in the Kara Sea, east of Novaya Zemlya [45]. While previously drilling was done using the 
Norwegian-built West Alpha rig, it is not clear from publicly available reports which rig Rosneft' has been using in recent years.

Moreover, while Rosneft's partnerships with Statoil and Eni for offshore development in the Sea of Okhotsk and the Barents Sea are on hold, there seems to be no change in long-term 'strategic cooperation' [44]. Close cooperation also continues with regards to the onshore Arctic fields, in which Statoil holds a 33.33\% stake [46]. As the contractual arrangements were made before the sanctions, the field is located just south of the Arctic Circle, and onshore, such cooperation is exempt from both Russian and EU restrictions.

Konoplyanik et al. point out that a distinction should be made between shallow and deepwater Arctic drilling. They argue that while sanctions hampered cooperation with western companies for shallow-water drilling, they did not affect any deepwater developments, as western partners also did not have established technologies for such drilling [12]. This assessment was correct at the time, since until recently drilling in Arctic waters occurred either off artificial islands (Alaska) or in shallow waters, such as Prirazlomnoye (19-20 meters) or Burger J prospect in Alaska (about $45 \mathrm{~m}$ ). However, since then, Arctic drilling in deeper waters has taken place in Norway, with examples such as the Gøliat field (360-420 meters) and the upcoming Johan Castberg development (360-390 meters), both of which use FPSOs (floating productions, storage, and offloading unit). While Norway is not part of the EU, the Norwegian government has decided to mirror the EU sanctions [47]. So far, the equipment ban has not resulted in the complete abandonment of petroleum projects in the Russian Arctic, but has rather led to delays and, consequently, the use of Asian equipment and the accelerated development of domestic technologies. Nevertheless, it is still premature to state that the lack of access to western technologies was substituted, especially since the current oil price climate puts any new Arctic production under question in the near-term. 


\subsection{Individual sanctions and financial restrictions}

It is not only equipment restrictions that impact resource development in the Russian Arctic. Personal sanctions against certain individuals and financial restrictions had direct and indirect impacts on Arctic projects, especially in the context of large costs associated with offshore oil production in the Russian Arctic [96].

As pertains to individual sanctions, the US regulator adopted a wide interpretation of the sanctions. In 2017, the US Office of Foreign Assets Control (OFAC) fined ExxonMobil USD 2 million for concluding deals with Rosneft' - even before Rosneft' had been included in the restriction list. The OFAC argued that Igor Sechin, the head of Rosneft' who had signed the agreements, was already included in restrictions in a personal capacity [48]. The decision has since been challenged in court by ExxonMobil, which asserts that they had been dealing with Mr Sechin not in his 'individual capacity', but rather with Rosneft' as a business - conduct that was at the time permitted under the sanctions [49]. In this context, it is important to note that as the interests of business and the State are so intertwined in Russia, particularly when it comes to the Arctic, any effects of sanctions on State petroleum companies will also affect the State policy in the region [50].

Another substantial factor potentially contributing to the halt of rapid development in the Russian Arctic is restricted access to foreign capital imposed by the sanctions. At the dawn of the imposition of sanctions, experts predicted that restriction of foreign capital would be more detrimental to Arctic petroleum development than the technology export ban $[12,16]$. Indeed, despite the initial halt in projects originally planned with western partners (e.g. 'Pobeda' field by Rosneft'-ExxonMobil partnership), as discussed above, the new projects are now going ahead without their involvement [45]. 
Some petroleum development projects in the Russian Arctic were indeed postponed after the imposition of sanctions. However, it would be unfair to attribute this solely to the sanctions regime. Konoplyanik et al. argue that a number of other factors contribute to the downshift in exploration and production activities, including low oil prices, high environmental risks, and lack of reliable technologies [12]. Indeed, the rollback of ambitious Arctic resource exploration plans is not unique to Russia but is also present in Canada, the US, and Greenland [51]. The next section considers the potential effects of sanctions on the Russian Arctic resource development policies.

\section{Russian Arctic resource governance post-sanctions}

The Russian economy is heavily dependent on the continuous output of petroleum products and the increased utilisation of the NSR. The share of crude oil exports in the country's GDP is around $28 \%$ [52], and the latest oil price crash demonstrated exactly how much the Russian currency depends on its extractive sector. With maturing fields in the conventional locations and the warming Arctic, production must shift north and offshore to maintain a steady output of oil and gas to foreign markets. This section considers how Russian Arctic development policies have been changing since the adoption of sanctions. To that end, it considers prioritising resource development, nationalising the NSR' - and import substitution for technology and equipment.

\subsection{Prioritising resource development: State support for Arctic petroleum projects}

As discussed in section 2, resource development has been at the core of Russia's Arctic policy long before the imposition of sanctions. Arctic petroleum projects, such as Yamal-LNG and 
Prirazlomnaya, received subsidies, tax breaks, and infrastructure support from the State. While State support for Arctic projects was already significant before the adoption of sanctions, it appears that lobbying for ever-increasing support and direct access to the ruling elite has become more important for the companies' performance in recent years [53].

The Prirazlomnaya project has been enjoying the export duty rebate, reduced mineral extraction tax, and property taxes. Experts argued that the project could be economically viable even without such extensive State support [54], although this is more difficult to imagine with the current oil prices.

A more illustrative example is the Yamal LNG project, owned by Gennadiy Timchenko, a member of President Putin's inner circle lobbying for the interests of the energy sector [55]. State support for the project has been unprecedented, starting with Putin's order to liberalise the LNG export market, effectively limiting Gazprom's monopoly [56]. In addition to tax breaks, the Yamal LNG project has also received substantial infrastructure support, such as the construction of the Sabetta port and airport, and launch of icebreaking and LNG tanker fleets [54]. While Yamal LNG is exporting substantial volumes gas to, inter alia, Japan and the UK, the tax breaks it receives are substantially high. Further, Yamal LNG also receives large direct subsidies from the National Welfare Fund (NWF). Thus, in 2015, a sum of USD 2.3 bln was transferred to Yamal LNG [57]. This is not a unique occurrence - after sanctions were adopted, NWF also provided finance for Rosneft' [53].

The future of State support for Arctic projects is currently uncertain. While there was a moratorium on new tax breaks for Arctic offshore projects until the end of 2019, a set of major tax breaks may be approved in the nearest future. A draft federal law 'On State Support for Business Activities in the Arctic Zone of the Russian Federation' [58], if adopted, would provide substantial tax breaks for new projects in Russian Arctic waters. However, at the time 
of writing of this article, the draft law was still in consideration, and it was expected that substantial amendments would be made.

\subsection{The Northern Sea Route}

In one of his speeches, Putin called the NSR 'the key to the development of the Russian Arctic and Far East' [59]. Indeed, the NSR is fundamental for the socio-economic development of the Russian Arctic [60], energy resource development [61], and the formulation of Arctic policy [62].

Shipping along the NSR started during Soviet times and the tonnage has been gradually increasing over the last six years, reaching $31 \mathrm{mln}$ tons in 2019 [63] (see Table 2 below).

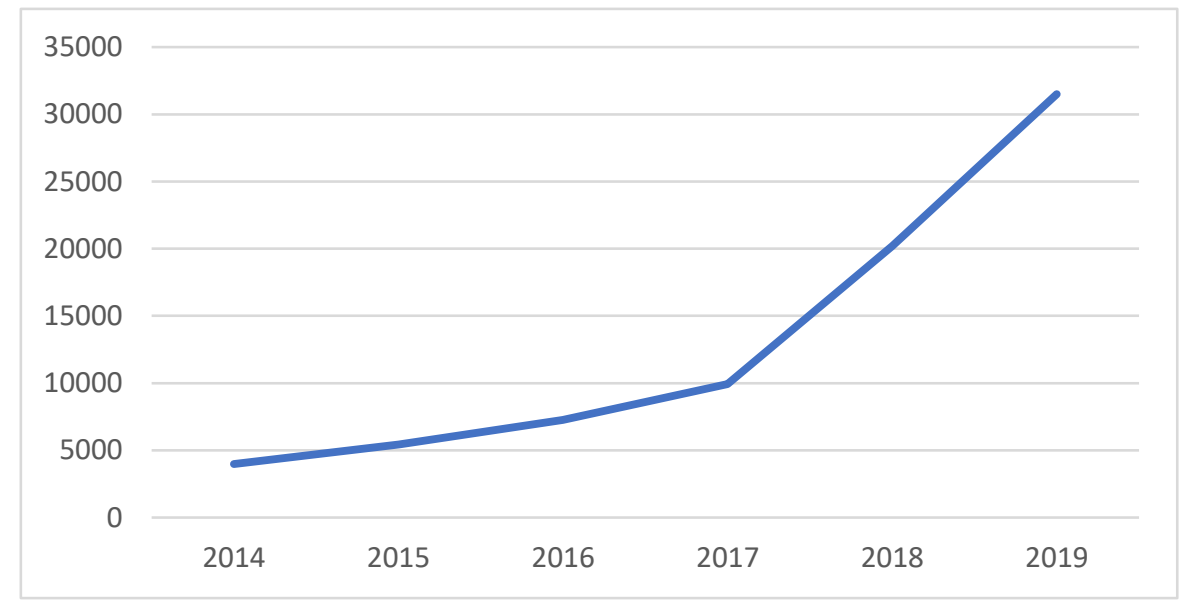

Table 2. Shipping tonnage on NSR (thousands of tons)

Source: State statistics [63]

The Russian Government has set an ambitious goal of reaching 80 mln tons of shipping tonnage along the NSR by 2024 [64]. Melting of Arctic sea ice will facilitate this increased traffic, but 
experts offer more modest predictions [65,66]. Increased shipping traffic along the Russian Northern coast is intrinsically linked with the Yamal-LNG and other Arctic petroleum developments. Although sanctions do not directly address the NSR, any potential increased shipping traffic depends not only on external factors, but also on the availability of resources in the State budget to invest in the construction and renovation of seaports and other important infrastructure ensuring safe shipping along the route [67]. The impact of sanctions on the NSR is indirect - through the slowdown of the offshore activities and subsequent slowdown in the shipping traffic.

The key issue at hand is ensuring the loading of the NSR at the target level of 80 million tons by 2024 [64]. However, the extraction of petroleum resources in this region is not profitable under current price and tax conditions. In order to stimulate production, significant mineral extraction tax benefits are needed, otherwise the target indicators will not be achieved. Largely because of this, the forecasts for achieving the target vary widely: from 60 to 110 million tons by 2024 [68-70]. In all forecasts, the main part will fall on the transportation of LNG by NOVATEK. To meet these targets, Novatek was granted an exemption from the Merchant Shipping Act requirements to allow the use of foreign LNG carriers [97].

\subsection{Import substitution: looking to the East?}

When western technology was first made unavailable, the development of the Russian Arctic shelf projects stagnated at the exploration stage. To move forward, the Russian government and main corporate players had to invest in the capacity to develop technologies domestically while looking for new partners in the East. In this context, private companies press for the liberalisation of the offshore legal regime so as to grant them access to the continental shelf along with State companies [71]. The sanctions drive Russian authorities to look for new 
partnerships in the East - Rosneft' reportedly signed preliminary agreements for Arctic developments with Chinese CNPS, Japanese INPEX, and Vietnamese PetroVietnam [72]. Gazprom is using a Chinese oil rig (Nanhai VIII) for exploratory work in the Kara Sea; and services its Arkticheskaya oil rig in Singapore [73]. China is also investing in existing projects in the Russian Arctic. Thus, the Chinese national oil company CNPC, in partnership with the Silk Road Fund, own 29.9\% of the Yamal LNG liquefying plan [74]. Chinese companies own $20 \%$ in another Novatek project 'Arctic LNG-2' [75]. Some commentators are nevertheless sceptical about the extent of Sino-Russian cooperation in the Arctic. Thus, Baev cites potential conflicts between the two countries with regards to the NSR navigation, and suggests that the Yamal LNG is 'the only success story in the ambivalent pattern of Russia-China cooperation in the Arctic' [76].

The officials view sanctions not just as a hurdle but an opportunity to develop the necessary technologies domestically, which in turn, would make Arctic resource development projects more economically feasible. In March 2018, then Deputy Minister of Energy said:

'[s]everal years ago, the pressure from the sanctions and the impossibility of using foreign equipment became a serious challenge for Arctic projects. There are not so many companies around the world with technologies and equipment capable of withstanding the harsh Arctic climate, but our task is for Russian oil and gas companies to become one of them' [77].

Indeed 'importozameshchenie' (or import substitution) became a flagship policy in the wake of the sanctions fight between Russia and the West [78]. Local content is increasing in Russian Arctic resource development. Thus, drilling rigs for Yamal LNG were constructed in Russia [79]. In the spring of 2014, amidst the sanctions' adoption, Rosneft' published a list of equipment and technology required for offshore petroleum development with the aim of 
'assisting Russian equipment manufacturers' [80]. At the federal level, the Ministry of Industry and Trade developed a plan for import substitution in petroleum industry equipment, including drilling rigs and LNG equipment [81]. A more long-term outlook set out in the Draft 2035 Energy Strategy also emphasizes the 'accelerated import substitution' in the petroleum industry sector [82].

Import substitution can appear controversial in the sustainability perspective. Russia's ambition to develop Arctic resources 'at all costs' leads to the perception that the benefits of such development overshadow any potential risks [92]. At the same time, environmental concerns over increased petroleum production and shipping along the NSR does not gain nearly as much attention from the Kremlin. Increased development and shipping will inevitably lead to rising air emissions from gas flaring and increased maritime traffic, operating discharges from drilling activities, and oil spills. Furthermore, activities in the Arctic carry additional risks associated with the harsh weather requirements and scarce infrastructure [93]. Fragile and unique Arctic ecosystems should not become the testing ground of the under-developed technologies, so it is important that any substituted equipment is thoroughly tested before deployment in the Arctic waters.

\subsection{Towards access liberalisation?}

While since 2009, the only companies with access to apply for offshore Arctic licenses were Gazprom and Rosneft' (see section 3.1), State policy directions appear to be shifting towards access liberalisation to allow privately-owned Russian companies to be license-holders. The Draft 2035 Energy Strategy considers widening access to offshore licenses to private companies 'with the necessary experience and financial resources' and creating long-term favourable investment climate to 'accelerate the development of the Arctic Zone of the Russian 
Federation' [84]. The wording of the draft suggests that while the State ownership requirement is likely to be relaxed, there would still be strict requirements for potential Arctic offshore licensees. One of the proposed access mechanisms is inspired by the Norwegian Joint Operating Agreement model, whereby private Russian and foreign companies might get shares in a specially created consortium, while the State company would retain $30 \%$ of the license share and act as an operator [71]. At the moment, this initiative is in the initial stages of legislative drafting, without any specific timeline available. If adopted, this model would only apply to less attractive license blocks which are still left unallocated (about 10\% of the Russian Arctic shelf). Moreover, no prospecting or exploration has been conducted on those blocks, and their development will be associated with additional costs and risks [83]. The Fundamentals of Russian Arctic policy, updated in March 2020, do not mention sanctions directly but refer to 'foreign States and international organisations preventing lawful commercial activities in the Russian Arctic' as a challenge for national security. Priority tasks for economic development in the Arctic, according to this policy document, include State support for commercial activities and 'widening the participation of private investors in Arctic continental shelf projects, while maintaining State control over their implementation' [94].

\subsection{Ambition vs reality}

It is not only the sanctions that hinder production but the present-day technologically challenging environment and unfavourable market conditions as well. The infamous Shtokman development, $650 \mathrm{~km}$ off Murmansk, is believed to hold 3.8 trillion cubic meters of gas [84]. Discovered in 1988, Shtokman was delayed by the involved partners' disagreements on how to develop the technically challenging field, the financial crisis, and finally by the shale gas boom in the US and the subsequent gas price drop [84]. In 2013, Shtokman development was 
postponed to after 2020 or even later as 'initial partners Gazprom, Total and Statoil did not take a final investment decision about challenges related to project design and costs' [72]. In 2019, it was reported that Shtokman development, long hailed to boost LNG sales, has been abandoned [85].

In September 2016, the Russian government announced a temporary moratorium on issuing new licenses on the Arctic shelf. While the decision was based on the lack of market stability, it has since been made clear that lifting the moratorium will be considered upon the request of the relevant companies [86]. At the same time, Gazprom and Rosneft' already hold collectively almost 50 licenses in the Russian Arctic waters, so the moratorium is not an indication of slowing down resource development ambitions [51].

Generally, the oil market conditions at the moment are not favourable towards Russian Arctic oil development which requires the price of over 100 USD per barrel to break even [96; 98]. With already substantial State support for Arctic petroleum projects, it is reasonable to expect some projects to be on hold to allow for market recovery especially in the context of the March 2020 oil price crash [99].

While there is a discernible decline in the rate of petroleum development in the Russian Arctic in the post-sanctions period, it is important to establish that the original ambitious goals for their development might not have been realistic. The same applies to the NSR, where the Government's shipping tonnage goals are arguably unattainable, according to the experts' forecasts (see section 4.2). The reasons behind setting such ambitious goals in the first place are often political and ideological, rather than economic. Arctic exploration and development are an important part of Russian foreign policy and identity [6]. It has symbolic value to demonstrate the dignity of Russian industry under the sanctions regime, and its adherence to the commitments that have been undertaken [87]. Russian actions in the Arctic often have 
elements of symbolic gestures that strengthen Russia's 'Arctic nation' identity, from being the first country to develop Arctic offshore oil and lodge extended continental shelf submissions with the UN Commission to planting a titanium flag on the seabed under the North Pole [12].

\section{Conclusions and policy implications}

The Arctic region has historically been seen as a resource base in Russia, although throughout various changes in political regimes, the governance approach has adapted. The latest turning points in Russian Arctic resource governance came in 2008 with the adoption of new policy documents, strengthening of State control over offshore petroleum development. The sanctions adopted by the EU and US were followed by ever-increasing State support for Arctic projects, import substitution, and a path towards liberalisation of access to the Arctic shelf.

Western sanctions, in the context of Arctic petroleum development, are pursuing long-term rather than short-term goals. After five years, their effects on the industry is believed to be negligible [15]. Analysis in this paper concurs with the existing studies in that the short-term effects on the upstream projects have so far been minimal and only resulting in temporary postponements. In broad terms, Arctic resources governance ambition has not changed either. Most discoveries were made during Soviet times, which consisted of a large investment in development in the North. State priorities in resource and NSR development policies were put in place long before the sanctions and indeed remain relevant today.

At the same time, sanctions have forced some changes in resource governance, namely the establishment of the import substitution priorities through the development of domestic technologies and cooperation with Asian countries. Russia's ties with China comprise the fundamental element of such cooperation against the background of the crisis with western 
partners. China, however, can only provide only access to finance, rather than large-scale technology and equipment. Furthermore, the implementation of this alternative scenario, substituting all western technology and finance with domestic resources and new Asian partners is not going to be quick especially considering the numerous path-dependencies in the Russian energy sector [96].

An important potential change in Arctic resource governance is the liberalisation of access to offshore licenses with private companies joining Gazprom and Rosneft'. The 2013 decision to limit Gazprom's gas export monopoly for Novatek's Yamal LNG was an unusual one against the backdrop of long-established pipeline export to Europe [89]. With Novatek's success, it is slowly becoming part of the Kremlin's strategy in the diversification of supply markets with Asian LNG exports showing the biggest growth [90]. While it appears to be a silver lining against the backdrop of western sanctions, the growing competition in the LNG market might make the Russian position incomparable with its decades of dominance on the European market.

One way or another, the Russian State is clear about its preparedness to provide support to its producers amidst the sanctions to meet the ambitious production and NSR development goals. The complexity and diversification of the resource base will inevitably be followed by structural changes in the governance of the petroleum industry [91]. The liberalisation of access, in this context - is a logical next step. While conventional sources of oil and gas are depleting, more challenging to develop deposits, many of which are located in the Arctic, will need to be developed to sustain the desired production rates. This, however, does not solve the other challenges of Arctic operations, not unique to Russia. With the global push for the energy transition, falling oil prices, and ever-growing environmental concerns over Arctic oil development and shipping, some Arctic projects will lose their economic attractiveness even for output sustainability. 


\section{Bibliography}

[1] R. Sidortsov, The Russian Offshore Oil and Gas Regime: When Tight Control Means Less Order, in: C. Pelaudeix, E.M. Basse (Eds.), Governance of Arctic Offshore Oil and Gas, Routledge, 2017.

[2] R. Sidortsov, Measuring Our Investment in the Carbon Status Quo: Case Study of New Oil Developmen in the Russian Arctic, Vt. J. Envtl. L. 13 (2011) 613-650.

[3] R. Sidortsov, Creating Arctic Carbon Lock-In: Case Study of New Oil Development in the South Kara Sea, CCLR. (2012) 3-10.

[4] V.-P. Tynkkynen, S. Tabata, D. Gritsenko, M. Goto, (Eds.), Russia’s Far North: The Contested Energy Frontier, Routledge, Abingdon/New York, 2018.

[5] G. Hønneland, Arctic Politics, the Law of the Sea and Russian Identity, Palgrave Pivot, London/New York, 2014.

[6] G. Hønneland, Russia and the Arctic: Environment, Identity and Foreign Policy, I.B.Tauris, London, 2015.

[7] D.H. Claes, A. Moe, Arctic Offshore Petroleum: Resources and Political Fundamentals, in: S.V. Rottem, I.F. Soltvedt (Eds.), Arctic Governance: Energy, Living Marine Resources and Shipping, I.B.Tauris, London, 2018: pp. 9-25.

[8] D.H. Claes, A. Moe, S.V. Rottem, Arctic Hydrocarbon Development: State Interests and Policies, in: S.V. Rottem, I.F. Soltvedt (Eds.), Arctic Governance: Energy, Living Marine Resources and Shipping, I.B.Tauris, London, 2018: pp. 26-50. 
[9] A. Bourmistrov, F. Mellemvik, A. Bambulyak, O. Gudmestad, I. Overland, A. Zolotukhin, International Arctic Petroleum Cooperation: Barents Sea Scenarios, Routledge, 2015.

[10] V.V. Gavrilov, Legal Status of the Northern Sea Route and Legislation of the Russian Federation: A Note, Legal Status of the Northern Sea Route and Legislation of the Russian Federation: A Note. 46 (2015) 256-263. https://doi.org/10.1080/00908320.2015.1054746.

[11] I. Øverland, Russia’s Arctic Energy Policy, Intl J. 65 (2009) 865-878.

[12] A. Konoplyanik, B. Buzovskiy, Y. Popova, V. Troshina, The Effects of Anti-Russian Sanctions on Realising the Potential of Russian Arctic Offshore Petroleum and Russian Energy Policy [Vliyanie antirossiiskih sanktsiy na osvoenie neftegazovogo potentsiala rossiiskogo arkticheskogo shel'fa - i razvilki energeticheckoi politiki Rossii], VostokKapital, Moscow, 2015.

[13] P. Aalto, T. Forsberg, The Structuration of Russia's Geo-economy under Economic Sanctions, Asia Europe Journal. 14 (2016) 221-237. https://doi.org/10.1007/s10308015-0446-6.

[14] A.A. Shirov, A.A. Yantovskii, V.V. Potapenko, Evaluation of the Potential Effect of Sanctions on the Economic Development of Russia and the European Union, Stud. Russ. Econ. Dev. 26 (2015) 317-326. https://doi.org/10.1134/S1075700715040103.

[15] T. Mitrova, E. Grushevenko, A. Malov, The Future of Oil Production in Russia: Life under Sanctions, Skolkovo, 2018. https://energy.skolkovo.ru/downloads/documents/SEneC/research04-en.pdf (accessed November 30, 2019). 
[16] D. Fjærtoft, I. Øverland, Financial Sanctions Impact Russian Oil, Equipment Export Ban's Effects Limited, Oil and Gas Journal. 113 (2015) 66-72.

[17] M. Ivanova, E. Klyukina, Contemporary Preconditions for the Future of the Arctic Labour Resources [Sovremennye predposylki budushchih arkticheskih trudovyh resursov], Sociology of Labour. 6 (2017) 180-198. https://doi.org/10.14515/monitoring.2017.6.08.

[18] D. Maximova, Sustainable Development of the Russian Arctic Zone: Challenges \& Opportunities, Arctic Yearbook. (2018). https://arcticyearbook.com/arcticyearbook/2018/2018-scholarly-papers/287-sustainable-development-of-the-russianarctic-zone-challenges-opportunities (accessed November 30, 2019).

[19] A.E. Kontorovich, Ways of Developing Oil and Gas Resources in the Russian Sector of the Arctic, Herald of the Russian Academy of Sciences. 85 (2015) 213-222. https://doi.org/10.1134/S1019331615030120.

[20] A. Petrov, Re-Tracing Development Paths: Exploring the Origins and Nature of the 20 th Century's Northern Development Paradigms in Russia and Canada, in: Arctic Yearbook 2018, 2018.

[21] V.V. Fauzer, Demographic Potential of Russian Northern Regions [Demograficheskiy potentsial severnyh regionov Rossii: faktor i usloviye ekonomicheskogo osvoyeniya Arktiki], Social'no Ekonomicheskie Problemy Regiona. (2014) 69-81.

[22] T.E. Heleniak, The Role of Attachment to Place in Migration Decisions of the Population of the Russian North, Polar Geography. 32 (2009) 31-60. https://doi.org/10.1080/10889370903000398. 
[23] V.N. Leksin, B.N. Profiriev, The Current State and Aims of State Management of the Socio-economic Development of the Russian Arctic: Legal Aspects [Sostoyaniye i zadachi gosudarstvennogo upravleniya sotsial'no-ekonomicheskim razvitiyem rossiyskoy Arktiki: pravovoy aspekt], Voprosy Gosudarstvennogo i Munitsipal'nogo Upravleniya. (2018) 114-138.

[24] Y. Adachi, Subsoil Law Reform in Russia under the Putin Administration, Europe-Asia Studies. 61 (2009) 1393-1414. https://doi.org/10.1080/09668130903134814.

[25] O. Gavshina, N. Vardul', K. Smirnov, The Tax Greenhouse [Nalogovaya teplitsa], Novoe Vremya. (2010). https://newtimes.ru/articles/detail/20009 (accessed December 1, 2019).

[26] K. Johnson, What's Really Happening with the Yukos Case, Foreign Policy. (2015). https://foreignpolicy.com/2015/06/19/whats-really-happening-with-the-yukos-caserussia-putin-belgium-france/ (accessed November 30, 2019).

[27] A. Pilyasov, From Paternalism to Partnership: Building New Relations between the Peoples of the North and the State [Ot paternalizma k partnerstvu: Stroitel'stvo novyh otnosheniy narodov Severa i gosudarstva], SVKNII DVO RAN, Magadan, 1998.

[28] Arctic Neighbours Draw Up Battle Lines, BBC. (2007). http://news.bbc.co.uk/1/hi/world/americas/6941569.stm (accessed May 21, 2019).

[29] P. Stauffer, US Geological Survey (USGS) Circum-Arctic Resource Appraisal: Estimates of Undiscovered Oil and Gas North of the Arctic Circle, (2009). http://library.arcticportal.org/1554/ (accessed November 30, 2019).

[30] The Fundamentals of the State Arctic Policy until 2020 and Further no PR-1969 (18 September 2008) [Ob osnovah gosudarstvennoy politiki Rossii v Arktike na period do 
2020 goda i dal'neyshuyu perspektivu] http://government.ru/info/18359/ (accessed November 30, 2019).

[31] Federal Law no 2395-1 “On Subsoil” [Federal'nyy zakon o nedrah], 1992. http://www.consultant.ru/document/cons_doc_LAW_343/ (accessed November 30, 2019).

[32] A. Krivorotov, M. Finger, State-Owned Enterprises in the Arctic, in: The GlobalArctic Handbook, 2018: pp. 45-62. https://doi.org/10.1007/978-3-319-91995-9_4.

[33] Strategy for the Russian Arctic Zone Development and Ensuring State Security until 2020 [Strategiya razvitiya Arkticheskoy zony Rossiyskoy Federatsii i obespecheniya natsional'noy bezopasnosti na period do 2020 goda], 2013. https://legalacts.ru/doc/strategija-razvitija-arkticheskoi-zony-rossiiskoi-federatsii-i/ (accessed November 30, 2019).

[34] Russian Government Decree no 366 "On the Approval of the State Programme 'On the Socio-Economic Development of the Russian Arctic Zone until 2020"” [Gosudarstvennaya programma Sotsial'no-ekonomicheskoye razvitiye Arkticheskoy zony Rossiyskoy Federatsii], 2014.

[35] Executive Order 13660 Blocking Property of Certain Persons Contributing to the Situation in Ukraine 79 (46) CFR 13493, (2014).

[36] Executive Order 13661 Blocking Property of Additional Persons Contributing to the Situation in Ukraine 79 (53) CFR 15535, (2014).

[37] Executive Order 13662 Blocking Property of Additional Persons Contributing to the Situation in Ukraine 79 (56) CFR 16169, (2014). 
[38] Council Regulation (EU) No 833/2014 Concerning Restrictive Measures in View of Russia's Actions Destabilising the Situation in Ukraine, (2014).

[39] E. Sidorova, Russian Energy Industry under Western Sanctions [Energetika Rossii pod sankciyami zapada], Mezhdunarodnye Protsessy. 44 (2016) 143-155.

[40] A.A. Bardin, E.S. Kuvshinov, Regulation of Investment Cooperation between Russian and Foreign Companies for the Realisation of Subsoil Development Projects in Russian Federation [Pravovoye regulirovaniye investitsionnogo sotrudnichestva mezhdu rossiyskimi i inostrannymi kompaniyami pri realizatsii proyektov po razrabotke nedr Rossiyskoy Federatsii], Direct Media, Moscow/Berlin, 2015.

[41] T. Makhmutov, D. Polosina, A. Kosivets, Sanctions Activity of the US and the EU in Regard to Russia: Consequences for Arctic Projects, 2018. https://russiancouncil.ru/en/analytics-and-comments/analytics/sanctions-activity-of-theus-and-the-eu-in-regard-to-russia-consequences-for-arctic-projects/ (accessed November 30, 2019).

[42] V. Buzovskiy, Analysis of Russian Arctic Shelf Development: Comparing Strategies of Rosneft' and Gazprom [Faktornyy analiz usloviy osvoeniya arkticheskogo shel'fa RF: Razlichiya strategiy PAO NK Rosneft' i PAO Gazprom], Pro-Arctic, 2016. http://proarctic.ru/01/11/2016/resources/23925 (accessed November 30, 2019).

[43] Rosnneft', Gazprom, and Novatek Delayed Development of New Fields [Rosnneft', Gazprom, and Novatek otlozhili vvod novyh mestorozhdeniy], RBC. (2015). https://www.rbc.ru/business/08/11/2015/563ccff59a7947d914eb3a14 (accessed November 30, 2019). 
[44] A. Staalesen, They Found One of Russia's Biggest Arctic Oil Fields, but Now Abandon It, The Independent Barents Observer. (2018).

https://thebarentsobserver.com/en/industry-and-energy/2018/03/they-found-one-russiasbiggest-offshore-arctic-oil-field-now-abandon-it (accessed June 26, 2019).

[45] A. Staalesen, Russia's Biggest Oil Company Announces More Offshore Arctic Drilling, The Barents Observer. (2019). https://thebarentsobserver.com/en/industry-andenergy/2019/07/russias-biggest-oil-company-announces-more-offshore-arctic-drilling (accessed November 30, 2019).

[46] A. Staalesen, This is Where Norway and Russia Continue Cooperation over Arctic Oil, The Barents Observer. (2017). https://thebarentsobserver.com/en/industry-andenergy/2017/09/where-norway-and-russia-continue-cooperation-over-arctic-oil (accessed November 30, 2019).

[47] Norwegian Ministry of Foreign Affairs, Regulations on Restrictive Measures Concerning Acts that Undermine or Threaten Ukraine's Territorial Integrity, Sovereignty, Independence and Stability [Forskrift om restriktive tiltak vedrørende handlinger som undergraver eller truer Ukrainas territorielle integritet, suverenitet, uavhengighet og stabilitet], (2014). https://lovdata.no/dokument/SF/forskrift/2014-0815-1076 (accessed November 30, 2019).

[48] D. Pilarski, ExxonMobil Sanctions Penalty: Lessons for Companies and Practitioners, New York Law Journal. (2017).

https://www.law.com/newyorklawjournal/sites/newyorklawjournal/2017/08/14/exxonm obil-sanctions-penalty-lessons-for-companies-and-practitioners/ (accessed November 30, 2019). 
[49] ExxonMobil Corp. et al. v Steve Mnuchin Civ. No. 3:17-cv-1930, (2017). https://cdn.exxonmobil.com/ /media/global/files/other/2017/exxonmobil-complaint.pdf (accessed November 30, 2019).

[50] N. Pankevich, Political and Legal Aspects of the Raw Materials Strategy of the Russian Federation and the United States in the Arctic [Politiko-pravovye aspekty syr'evoy strategii RF i SShA v Arktike], Mirovaja Ekonomika i Mezhdunarodnye Otnosheniya. 7 (2015) 97-110.

[51] D. Shapovalova, K. Stephen, No Race for the Arctic? Examination of Interconnections between Legal Regimes for Offshore Petroleum Licensing and Level of Industry Activity, Energy Policy. 129 (2019) 907-917.

[52] Russia (RUS) Exports, Imports, and Trade Partners, The Observatory of Economic Complexity. (nd). https://oec.world/en/profile/country/rus/\#Exports (accessed November 30, 2019).

[53] T. Mitrova, Shifting Political Economy of Russian Oil and Gas, Center for Strategic and International Studies, 2016. https://www.csis.org/analysis/shifting-political-economyrussian-oil-and-gas-0 (accessed November 30, 2019).

[54] L.P. Lunden, D. Fjaertoft, Government Support to Upstream Oil \& Gas in Russia: How Subsidies Influence the Yamal LNG and Prirazlomnoe Projects, The International Institute for Sustainable Development/WWF, Geneva, Oslo, Moscow, 2014.

[55] T. Gustafson, Wheel of Fortune: The Battle for Oil and Power in Russia, Harvard University Press, Cambridge, MA, 2012.

[56] Russian Government Order no 1277-r [Rasporiazhenie ot 14 iiulia 2014 No 1277-r], (2014). 
[57] Russia's “Anti-Crisis” National Wealth Fund: An Overview, The Moscow Times. (2015). https://www.themoscowtimes.com/2015/02/06/russias-anti-crisis-nationalwealth-fund-an-overview-a43639 (accessed November 30, 2019).

[58] Draft Law 'On the State Support for Business Activities in the Arctic Zone of the Russian Federation' [O gosudarstvennoi podderzhke investitsionnoy deyatel'nosti v Arkticheskoy Zone Rossiyskoy Federatsii], (2019).

http://www.consultant.ru/cons/cgi/online.cgi?req=doc;base=PRJ;n=183373\#042249424 241865796 (accessed November 30, 2019).

[59] A. Staalesen, It's an Order from the Kremlin: Shipping on Northern Sea Route to Reach 80 Million Tons by 2024, The Independent Barents Observer. (2018). https://thebarentsobserver.com/en/arctic/2018/05/its-order-kremlin-shipping-northernsea-route-increase-80-million-tons-2024 (accessed November 30, 2019).

[60] E.E. Plisetskiy, Priorities for the Development of the Northern Sea Route in Strategic Management and Planning [Prioritety razvitiya Severnogo morskogo puti v strategicheskom upravlenii i planirovanii], Arktika i Sever. 22 (2016) 103-113.

[61] A. Konovalov, Transport Infrastructure of the Russian Arctic: Problems and Solutions [Transportnaya infrastruktura rossiyskoy Arktiki: problemy i puti ih resheniya], Arktika: Zona Mira i Sotrudnichestva. (2011) 120-142.

[62] A.N. Pilyasov, V.V. Kuleshov, V.E. Seliverstov, Arctic Policy in An Era of Global Instability: Experience and Lessons for Russia, Reg. Res. Russ. 5 (2015) 10-22. https://doi.org/10.1134/S2079970515010086.

[63] Fedstat, Shipping Tonnage Volume along the NSR, (2019). https://fedstat.ru/indicator/51479 (accessed November 30, 2019). 
[64] President's Order no 204 'On national targets and strategic objectives in the Russian Federation until 2024'[O natsional'nyh tselyah i strategicheskih zadachah razvitiya Rossiiskoy Federatsii do 2024], (2018). http://kremlin.ru/events/president/news/57425 (accessed November 30, 2019).

[65] I.V. Benedyk, S. Peeta, A Binary Probit Model to Analyze Freight Transportation Decision-Maker Perspectives for Container Shipping on the Northern Sea Route, Marit Econ Logist. 20 (2018) 358-374. https://doi.org/10.1057/s41278-016-0046-4.

[66] D. Yumashev, K. van Hussen, J. Gille, G. Whiteman, Towards a Balanced View of Arctic Shipping: Estimating Economic Impacts of Emissions from Increased Traffic on the Northern Sea Route, Climatic Change. 143 (2017) 143-155. https://doi.org/10.1007/s10584-017-1980-6.

[67] S. Kirchner, Beyond the Polar Code: Enhancing Seafarer Safety along the Northern Sea Route, J. Sib. Fed. Univ., Humanit. Soc. Sci. 11 (2018) 365-373. https://doi.org/10.17516/1997-1370-0230.

[68] Russian Federation Ministry of Natural Resources, Comprehensive Plan 'Implementation of the Arctic's Mineral and Raw Materials and Logistics Potential' [Kompleksnyy plan Realizatsiya mineral'no-syr'yevogo i logisticheskogo potentsiala Arktiki], 2019.

http://www.mnr.gov.ru/press/news/kompleksnyy_plan_realizatsiya_mineralno_syrevog o_i_logisticheskogo_potentsiala_arktiki_razrabotannyy/(accessed November 30, 2019).

[69] Russian Government Decree no 2101-r 'On the Approval of a Comprehensive Plan for the Modernisation and Expansion of the Main Infrastructure until 2024' [Ob utverzhdenii Kompleksnogo plana modernizatsii i rasshireniya magistral'noy 
infrastruktury na period do 2024 goda], 2018. http://government.ru/docs/34297/ (accessed November 30, 2019).

[70] The Northern Sea Route is the Key to the Development of the Russian Arctic [Severnyy morskoy put' — klyuch k razvitiyu rossiyskoy Arktiki], Roskongress. (2019). https://roscongress.org/news/severnyj-morskoj-put-kljuch-k-razvitiju-rossijskoj-arktiki/ (accessed November 30, 2019).

[71] Trutnev Suggested Providing Access to Offshore Licenses to Foreign Companies Using the Norwegian Model [Trutnev predlozhil dopustit' inostrantsev na shel'f po norvezhskoy modeli], RBC. (2019).

https://www.rbc.ru/business/19/08/2019/5d566ab49a7947078cda33b5 (accessed November 30, 2019).

[72] International Energy Agency, Russia 2014: Energy Policies beyond IEA Countries, 2014.

[73] On the Way to Kara Sea. Drilling Rigs Arkticheskaya and Nanhai VIII Left the Port of Murmansk [Na puti k Karskomu moryu. Burovye platformy Arkticheskaya i Nanhai VIII vyshli iz porta Murmansk], (2018). https://neftegaz.ru/news/Geologicalexploration/199847-na-puti-k-karskomu-moryu-burovye-platformy-arkticheskaya-inanhai-viii-vyshli-iz-porta-murmansk/ (accessed November 30, 2019).

[74] About the Project, Yamal LNG. (n.d.). http://yamallng.ru/en/project/about/ (accessed December 6, 2019).

[75] M. Humpert, China Acquires 20 Percent Stake in Novatek's Latest Arctic LNG Project, High North News. (2019). https://www.highnorthnews.com/en/china-acquires-20percent-stake-novateks-latest-arctic-lng-project (accessed December 6, 2019). 
[76] P.K. Baev, Examining the Execution of Russian Military-Security Policies and Programs in the Arctic, in: V.-P. Tynkkynen, S. Tabata, D. Gritsenko, M. Goto (Eds.), Russia's Far North: The Contested Energy Frontier, Routledge, Abingdon/New York, 2018: pp. 113-125.

[77] K. Molodtsov on Potential Petroleum Development in the Arctic [K. Molodtsov rasskazal o perspektivah neftegazodobychi v Arktike], (2018). https://neftegaz.ru/news/dobycha/202600-k-molodtsov-rasskazal-o-perspektivakhneftegazodobychi-v-arktike/ (accessed November 30, 2019).

[78] S. Tolkachev, A. Teplyakov, Import Substitution in Russia: The Need for a SystemStrategic Approach, Problems of Economic Transition. 60 (2018) 545-577. https://doi.org/10.1080/10611991.2018.1551033.

[79] WMT Consult, Arctic: How to Awaken to Idle Region [Arktika; kak razbudit' spyashchiy region], Neftegazovaya Vertikal', 2019. http://www.ngv.ru/upload/iblock/8bd/8bd3cce6338529d05a0ca03367ee81c9.pdf (accessed November 30, 2019).

[80] Offshore Equipment [Oborudovanie dlya shel'fa], Rosneft'. (nd). https://www.rosneft.ru/business/Upstream/shelf_equipment/ (accessed December 1, 2019).

[81] Russian Federation Ministry of Industry and Trade Order no 645 "On the Action Plan for Import Substitution in Petroleum Industry Equipment” [Ob utverzhdenii plana meropriyatiy po importozameshcheniyu v otrasli neftegazovogo mashinostroyeniya Rossiyskoy Federatsii], (2015). https://rulaws.ru/acts/Prikaz-Minpromtorga-Rossii-ot31.03.2015-N-645/ (accessed November 30, 2019). 
[82] Russian Federation Ministry of Energy, Draft Energy Strategy until 2035 (October 2019) [Proekt Energeticheskoy Strategii do 2035 goda], (n.d.). https://minenergo.gov.ru/node/1920 (accessed November 30, 2019).

[83] The Russian Government is Preparing a Bill on the Admission of Private Investors to the Development of the Arctic Shelf [Pravitel'stvo RF gotovit zakonoproyekt o dopuske chastnyh investorov k osvoyeniyu arkticheskogo shel'fa], Neftegaz. (2019). https://neftegaz.ru/news/gosreg/482926-pravitelstvo-rf-gotovit-zakonoproekt-odopuske-chastnykh-investorov-k-osvoeniyu-arkticheskogo-shelfa/ (accessed December 1, 2019).

[84] J. Henderson, J. Loe, The Prospects and Challenges for Arctic Oil Development, The Oxford Institute for Energy Studies, 2014.

[85] A. Staalesen, No More Shtokman Development, The Independent Barents Observer. (2019). https://thebarentsobserver.com/en/industry-and-energy/2019/06/no-moreshtokman-development (accessed June 22, 2019).

[86] I. Mandrykina, Sergey Donskoy: It Is too Early to Talk About Market Stability [Sergey Donskoy: govorit' o stabilizatsii rynka nefti rano], TASS. (2018). https://tass.ru/forumsochi2018/articles/4962147 (accessed November 30, 2019).

[87] E. Galimullin, Y. Matveenko, The Ongoing Formation of Russia's Arctic Policy: A New Stage?, Arctic Yearbook. (2019).

[88] N. Andreassen, Arctic Energy Development in Russia-How "Sustainability" Can Fit?, Energy Research \& Social Science. 16 (2016) 78-88. https://doi.org/10.1016/j.erss.2016.03.015. 
[89] M. Schach, R. Madlener, Impacts of an Ice-free Northeast Passage on LNG markets and geopolitics, Energy Policy. 122 (2018) 438-448.

https://doi.org/10.1016/j.enpol.2018.07.009.

[90] A. Vatansever, Is Russia Building Too Many Pipelines? Explaining Russia’s Oil and Gas Export Strategy, Energy Policy. 108 (2017) 1-11.

https://doi.org/10.1016/j.enpol.2017.05.038.

[91] V. Kryukov, A. Moe, Does Russian Unconventional Oil Have a Future?, Energy Policy. 119 (2018) 41-50. https://doi.org/10.1016/j.enpol.2018.04.021.

[92] R. Sidortsov, Benefits over Risks: A Case Study of Government Support of Energy Development in the Russian North, Energy Policy. 129 (2019) 132-138. https://doi.org/10.1016/j.enpol.2019.01.067.

[93] D. Shapovalova, International Governance of Oil Spills from Upstream Petroleum Activities in the Arctic: Response over Prevention?, International Journal of Marine and Coastal Law. 34 (2019) 668-697. https://doi.org/10.1163/15718085-23342029

[94] The Fundamentals of the State Arctic Policy until 2035 no 164 (5 March 2020) [Ob osnovah gosudarstvennoy politiki Rossii v Arktike na period do 2035 goda] http://static.kremlin.ru/media/events/files/ru/f8ZpjhpAaQ0WB1zjywN04OgKiI1mAvaM .pdf (accessed 16 April, 2020).

[95] Merchant Shipping Code of the Russian Federation, no-81 FZ [Kodeks torgovogo moreplavaniya Rossiiskoy Federatsii], 1992. http://www.consultant.ru/document/cons_doc_LAW_22916/b550f882df9b43f2c6bbf7c8 f8c4bb1aa67e5a28/ (accessed April 16, 2020). 
[96] P. Aalto, Modernisation of the Russian Energy Sector: Constraints on Utilising Arctic Offshore Oil Resources, Europe-Asia Studies. 68 (2016) 38-63.

[97] M. Humpert, Novatek Allowed to Operate Foreign LNG Carriers on Northern Sea Route. (2019) High North News. https://www.highnorthnews.com/en/natural-gascompany-novatek-was-granted-exemption-new-law-banning-foreign-flagged-oil-and-gas (accessed April 16, 2020).

[98] Cost of Oil Production Country by Country. Knoema. n.d. https://knoema.com/vyronoe/cost-of-oil-production-by-country (accessed April 16, 2020).

[99] Oil Crashes to Fresh 18-year Low as Demand Suffers Unprecedented Drop, CNN (2020). https://edition.cnn.com/2020/03/30/business/oil-crash-gas-prices/index.html (accessed April 16, 2020). 